\title{
Penambahan Tepung Ikan Lele Dan Tepung Kedelai Pada Biskuit Modified Cassava Flour Untuk Lansia
}

\section{Addition of Catfish Flour and Soybean Flour to Modified Cassava Flour Biscuits for the Elderly}

\section{Rachmah Fathia Widyaniputria1a, Noli Novidahlia', Dwi Aryanti Nur'utami², CC Nurwitri ${ }^{3}$}

\begin{abstract}
1Jurusan Teknologi Pangan dan Gizi Fakultas Ilmu Pangan Halal Universitas Djuanda Bogor, Jl. Tol Ciawi No. 1, Kotak Pos 35 Ciawi, Bogor 16720.

aKorespondensi : Rachmah Fathia Widyaniputri, E-mail : rachmahfathia@gmail.com
\end{abstract}

(Diterima oleh Dewan Redaksi : 23 - 01 - 2020)

(Dipublikasikan oleh Dewan Redaksi : 08 - 04 - 2020)

\begin{abstract}
Elderly need adequate intake to prevent health problems. One of the intake can be obtained from snack such as biscuit. This study aims to improve nutritional quality in terms of fiber and protein by the addition of local food sources such as mocaf, catfish flour and soy flour as a source of protein. This research used catfish flour and soy flour with concentration about 11\%: 6\%, 14\%: 3\%, and 17\%: 0\%. Biscuit was hedonic testing by the elderly as untrained panelists, chemically consist proximate, crude fiber, total energy content and analyzed physically namely texture analysis (hardness). The results showed that the addition of $17 \%$ catfish flour and $0 \%$ soy flour was the most preferred biscuits from the parameters of color, aroma, texture, and taste. Nutrient content of were $3.69 \%$ water content, $3.12 \%$ ash content, $12.19 \%$ protein content, $29.23 \%$ fat content, $51.77 \%$ carbohydrate content, $1.37 \%$ crude fiber content, and a total energy $519 \mathrm{Kcal} / 100$ grams with a hardness value of $987.00 \mathrm{gf}$ (gramforce).
\end{abstract}

Keywords : biscuit, mocaf, catfish flour, soybean flour

\begin{abstract}
ABSTRAK
Lansia membutuhkan asupan yang cukup untuk mencegah masalah kesehatan. Salah satu asupannya bisa didapat dari camilan seperti biskuit. Penelitian ini bertujuan untuk meningkatkan kualitas gizi dalam hal serat dan protein dengan penambahan sumber makanan lokal seperti mocaf, tepung lele dan tepung kedelai sebagai sumber protein. Penelitian ini menggunakan tepung lele dan tepung kedelai dengan konsentrasi sekitar 11\%: 6\%, 14\%: 3\%, dan 17\%: 0\%. Biskuit adalah pengujian hedonik oleh lansia sebagai panelis yang tidak terlatih, secara kimia terdiri proksimat, serat kasar, kandungan energi total dan dianalisis secara fisik yaitu analisis tekstur (kekerasan). Hasil penelitian menunjukkan bahwa penambahan 17\% tepung lele dan 0\% tepung kedelai adalah biskuit yang paling disukai dari parameter warna, aroma, tekstur, dan rasa. Kandungan nutrisi adalah kadar air 3,69\%, kadar abu 3,12\%, kadar protein 12,19\%, kadar lemak 29,23\%, kadar karbohidrat $51,77 \%$, kadar serat kasar 1,37\%, dan energi total 519 Kcal / 100 gram dengan nilai kekerasan 987,00 gf (gramforce).
\end{abstract}

Kanta Kunci : biskuit, mocaf, tepung ikan lele, tepung kedelai,

Widyaniputri, Rachmah Fathia, Noli Novidahlia, Dwi Aryanti Nur'utami, CC Nurwitri. 2020. Penambahan Tepung Ikan Lele Dan Tepung Kedelai Pada Biskuit Modified Cassava Flour untuk Lansia. Jurnal Agroindustri Halal 6(1): 77- 86 


\section{PENDAHULUAN}

Peningkatan usia harapan hidup menyebabkan peningkatan jumlah penduduk usia lanjut (lansia) dari tahun ketahun. Bertambahnya jumlah penduduk dan usia harapan hidup lansia akan menimbulkan berbagai masalah, salah satu diantaranya yaitu masalah kesehatan. Masalah kesehatan disebabkan oleh penurunan fisiologis, diantaranya adalah penurunan fungsi pencernaan yang memberikan pengaruh pada sistem pencernaan yaitu beresiko menyebabkan kekurangan gizi pada lansia (Keithley 1996 dalam Meirina 2011). Oleh karena itu, diperlukan asupan yang cukup untuk lansia. Tidak hanya dari makanan utama, namun juga dari kudapan. Kudapan yang biasa dikonsumsi lansia salah satunya adalah biskuit.

Biskuit dibuat dari tepung terigu rendah gluten (protein rendah) ataupun tepung tanpa gluten karena produk jenis ini tidak memerlukan pengembangan volume yang besar (Midlanda et al. 2012). Penggunaan lemak dan gula yang relatif tinggi pada adonan biskuit umumnya tidak diimbangi dengan keberadaan serat (Septieni 2016). Oleh karena itu, perlu dilakukan diversifikasi terhadap produk biskuit untuk meningkatkan kandungan seratnya.

Pemanfaatkan sumber pangan lokal seperti penggunaan Mocaf (Modified cassava flour) dalam pembuatan biskuit dapat meningkatkan kandungan serat dan memiliki karakteristik yang berbeda terhadap produk yang dihasilkan. Namun, mocaf tidak memiliki kandungan gluten seperti tepung terigu, sehingga biskuit yang dihasilkan memiliki kandungan protein yang sangat rendah. Peningkatan kandungan protein dapat menjadi salah satu alternatif untuk meningkatkan kesehatan lansia. Sumber protein terdiri dari protein nabati dana hewani. Protein nabati memiliki kandungan asam amino yang tidak selengkap protein hewani, namun mencampurkan dua atau lebih

sumber protein yang berbeda dapat melengkapi kandungan proteinya. Oleh karena itu, penambahan tepung ikan lele dan tepung kedelai dapat meningkatkan kandungan protein dalam biskuit.

\section{METODE PENELITIAN}

\section{Materi}

Bahan yang digunakan dalam penelitian ini adalah mocaf, tepung kedelai, tepung ikan lele, sumber karbohidrat lain, gula, kacang-kacangan, perisa alami berbasis rempah, sumber minyak dan lemak, dan air.

Alat yang digunakan dalam penelitian ini adalah mangkuk stainless, timbangan, sendok, gelas ukur, loyang pemanggang, oven, nampan, kertas pemanggang, cetakan, dan spatula.

\section{Tempat dan Waktu Penelitian}

Penelitian dilaksanakan pada bulan Februari 2019 - Juli 2019. Penelitian dilaksanakan di laboratorium pengolahan pangan Universitas Djuanda Bogor, laboratoriun kimia dan laboratorium pengolahan Program Studi Supervisor Jaminan Mutu Pangan Sekolah Vokasi Institut Pertanian Bogor.

\section{Metode}

Pembuatan biskuit mocaf diawali dengan proses penimbangan bahan-bahan. Kemudian dilakukan pengayakan tepung dengan ukuran 40 mesh dan pencampuran bahan. Tepung ikan lele yang digunakan terdiri dari dua bagian, yaitu tepung badan ikan lele dan tepung kepala ikan lele yang dicampur dengan perbandingan 1:1. Tepung ikan lele dan tepung kedelai dengan perbandingan (11\% : 6\%, 14\% : 3\%, 17\% : 0\%) dicampurkan ke dalam bahan-bahan kering lainnya seperti mocaf, sumber karbohidrat lainnya, gula, kacang-kacangan halus dan perisa alami berbasis rempah. Setelah itu ditambahakan kacang almond Formulasi biskuit mocaf dapat dilihat pada Tabel 1. 
Dilanjutkan dengan proses pencampuran dan pengadonan dengan sumber minyak dan lemak, serta air. Lalu biskuit dicetak berbentuk lingkaran. Biskuit dipanggang dalam oven listrik dengan suhu $160^{\circ} \mathrm{C}$ selama 30 menit. Diagram alir pembuatan biskuit mocaf dapat dilihat pada Gambar 1.

Tabel 1. Formulasi biskuit mocaf

\begin{tabular}{lccc}
\hline \multirow{2}{*}{ Bahan } & \multicolumn{3}{c}{ Perlakuan } \\
\cline { 2 - 4 } & A1 & A2 & A3 \\
\hline $\begin{array}{l}\text { Tepung Ikan } \\
\text { Lele (\%) }\end{array}$ & 11 & 14 & 17 \\
$\begin{array}{l}\text { Tepung Kedelai } \\
\text { \%) }\end{array}$ & 6 & 3 & 0 \\
Mocaf (\%) & 21 & 21 & 21 \\
Sumber & 7 & 7 & 7 \\
Karbohidrat & & & \\
$\begin{array}{l}\text { Lain (\%) } \\
\text { Gula (\%) }\end{array}$ & 18 & 18 & 18 \\
$\begin{array}{l}\text { Kacang- } \\
\text { kacangan (\%) }\end{array}$ & 5 & 5 & 5 \\
$\begin{array}{l}\text { Perisa Alami } \\
\text { Berbasis }\end{array}$ & 1 & 1 & 1 \\
$\begin{array}{l}\text { Rempah (\%) } \\
\text { Sumber Minyak } \\
\text { dan Lemak(\%) }\end{array}$ & 20 & 20 & 20 \\
$\begin{array}{l}\text { Air (\% } \\
\text { Total (\%) }\end{array}$ & 11 & 11 & 11 \\
\hline
\end{tabular}

Biskuit tersebut selanjutnya dilakukan pengujian secara organoleptik oleh panelis lansia sebagai panelis tidak terlatih, dan analisis kimia dan analisis fisik berupa kekerasan. Uji organoleptik yang dilakukan yaitu, uji hedonik dengan skala (1-7) berdasarkan parameter warna, aroma, tekstur, dan rasa.

Kemudian dilakukan analisis kimia meliputi kadar protein, air, abu, lemak, serat kasar, karbohidrat (by difference) dan energi total. Analisis fisik (kekerasan) dengan texture analyzer. Produk terpilih ditentukan berdasarkan hasil uji organoleptik dan analisis kimia serta analisis fisik terbaik.

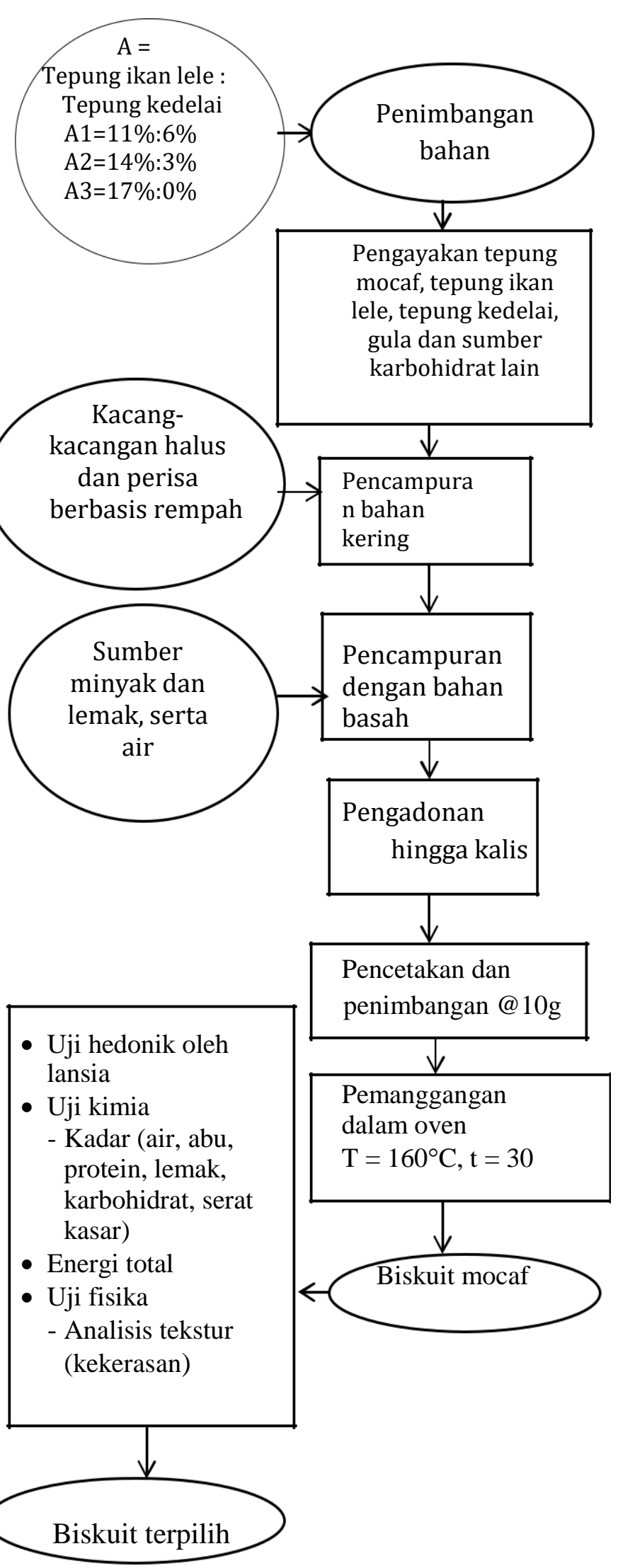

Gambar 1. Diagram alir pembuatan biscuit mocaf (Modifikasi Aini dan Wirawani 2013) 


\section{Analisis Produk}

Biskuit yang dihasilkan akan dianalisis yaitu uji hedonik (skala 1-7) dengan parameter warna, aroma, tekstur dan rasa yang dilakukan oleh 50 orang panelis lansia sebagai panelis sebagai tidak terlati. Kemudian dilakukan analisis kimia meliputi kadar air (BSN 2011a), abu (AOAC 2000), protein (BSN 2011a), lemak (AOAC 2000), serat kasar (BSN 1992), karbohidrat (BSN, 1992) dan energi total (Almatsier 2001), serta dianalisis kekerasan dengan menggunakan alat texture analyzer.

\section{Analisa Data}

Analisis data yang digunakan dalam penelitian ini adalah dengan menggunakan Microsoft Excel dan program SPSS 20 untuk mengetahui hasil analisis kimia dan kekerasan melalui analisis sidik ragam (ANOVA) dan uji hedonik melalui Uji Kruskal Wallis. Uji Kruskal Wallis $\mathrm{p}<0,05$ (berpengaruh nyata), maka untuk mengetahui perlakuan mana yang berbedaa nyata dilakukan uji lanjut dengan menggunakan uji Mann-Whitnney dengan taraf kepercayaan 95\% $(\alpha=0,05)$. Sedangkan jika hasil yang diperoleh dari ANOVA $p<0,05$ (berpengaruh nyata), maka dilakukan uji lanjut Duncan pada taraf kepercayaan 95\% $(\alpha=0,05)$.

\section{HASIL DAN PEMBAHASAN}

\section{Hasil Uji Hedonik}

Hasil uji hedonik yang dilakukan oleh panelis lansia terhadap parameter warna, aroma, tekstur dan rasa biskuit mocaf dapat dilihat pada Tabel 2 .

Tabel 2. Hasil uji hedonik biskuit mocaf

\begin{tabular}{cccc}
\hline Parameter & A1 & A2 & A3 \\
\hline Warna & $5,14 \mathrm{a}$ & $5,14 \mathrm{a}$ & $5,26 \mathrm{a}$ \\
Aroma & $5,40 \mathrm{a}$ & $5,54 \mathrm{a}$ & $5,46 \mathrm{a}$ \\
Tekstur & $5,40 \mathrm{a}$ & $5,60 \mathrm{a}$ & $6,06 \mathrm{~b}$ \\
Rasa & $5,36 \mathrm{a}$ & $5,58 \mathrm{a}$ & $5,56 \mathrm{a}$ \\
\hline
\end{tabular}

Keterangan : Huruf yang sama dalam satu baris menyatakan tidak berbeda nyata pada $\alpha=0,05$
A1 = Tepung Ikan Lele 11\%: Tepung

Kedelai 6\%

A2 = Tepung Ikan Lele 14\% : Tepung

Kedelai 3\%

A3 = Tepung Ikan Lele 17\% : Tepung

Kedelai 0\%

\section{Warna}

Berdasarkan hasil uji hedonik biscuit yang dilakukan oleh lansia, rata-rata nilai kesukaan terhadap warna biskuit berkisar 5,14-5,26 yang diketahui bahwa skor 5 menyatakan agak suka. Berdasarkan hasil uji Kruskal-Wallis, diketahui bahwa perbandingan tepung ikan lele dan tepung kedelai tidak berpengaruh terhadap tingkat kesukaan panelis pada parameter warna biskuit ( $p>0,05)$, sehingga tidak ada perbedaan tingkat kesukaan panelis terhadap warna setiap sampel biskuit mocaf.

Tingkat kesukaan panelis hanya mencapai tingkat 5 (agak suka) dapat disebabkan oleh warna coklat tidak cerah pada biskuit yang dihasilkan. Faktor yang dapat mempengaruhi warna yaitu dari warna bahan tepung yang digunakan dan reaksi maliard. Reaksi millard yaitu reaksireaksi antara karbohidrat, khususnya gula pereduksi dengan gugus amina primer. Sehingga akan menghasilkan bahan berwarna coklat (Winarno 2004).

\section{Aroma}

Berdasarkan hasil uji hedonik biscuit yang dilakukan oleh lansia, rata-rata nilai kesukaan terhadap aroma biskuit berkisar 5,40-5,54 yang diketahui bahwa skor 5 menyatakan agak suka. Berdasarkan hasil uji Kruskal-Wallis menunjukan bahwa perbandingan tepung ikan lele dan tepung kedelai tidak berpengaruh terhadap tingkat kesukaan panelis pada parameter aroma biskuit ( $\mathrm{p}>0,05)$, sehingga tidak ada perbedaan tingkat kesukaan panelis terhadap aroma setiap sampel biskuit mocaf.

Tingkat kesukaan panelis hanya mencapai tingkat 5 (agak suka) dapat disebabkan oleh aroma amis dari tepung ikan lele belum sepenuhnya dapat tertutupi 
oleh aroma perisa berbasis rempah. Menurut Nastiti dan Christyaningsih (2019), penambahan bahan dengan rasa kuat (perasa atau rempah) dapat digunakan sebagai alternatif dalam mengurangi rasa yang kuat pada biskuit yang dimodifikasi tepung ikan lele.

\section{Tekstur}

Berdasarkan hasil uji hedonik biskuit yang dilakukan oleh lansia, rata-rata nilai kesukaan terhadap tekstur biskuit berkiasar 5,40-6,06 yang diketahui bahwa skor 5 menyatakan agak suka dan skor 6 menyatakan suka. Berdasarkan hasil uji Kruskal-Wallis diketahui bahwa perbandingan tepung ikan lele dan tepung kpedelai berpengaruh nyata terhadap tingkat kesukaan panelis pada parameter tekstur biskuit ( $\mathrm{p}<0,05)$. Hasil uji lanjut Mann-Whitney diketahui bahwa tingkat kesukaan panelis terhadap tekstur sampel biskuit mocaf A1 tidak berbeda nyata dengan A2 ( $p>0,05)$, namun sampel biskuit mocaf A1 berbeda nyata dengan A3 (p < $0,05)$, dan sampel biskuit mocaf A2 tidak berbeda nyata dengan A3 ( $p>0,05)$.

Diketahui sampel biskuit mocaf A3 merupakan sampel yang paling disukai, karena menurut panelis biskuit tersebut memiliki tekstur yang padat dan renyah.
Menurut Aini dan Wirawani (2013), kerenyahaan identik dengan kerapuhan. Menutrut Pratama et al. (2014), penambahan tepung ikan pada biskuit menyebabkan tekstur biskuit lebih rapuh dibandingkan dengan biskuit tanpa modifikasi.

Rasa

Berdasarkan hasil uji hedonik biskuityang dilakukan oleh lansia, rata-rata nilai kesukaan terhadap rasa biscuit berkiasar 5,36-5,56 yang diketahui bahwa skor 5 menyatakan agak suka. Berdasarkan hasil uji Kruskal-Wallis diketahui bahwa perbandingan tepung ikan lele dan tepung kedelai tidak berpengaruh nyata terhadap tingkat kesukaan panelis terhadap rasa biskuit ( $p>0,05)$. Sehingga tidak ada perbedaan tingkat kesukaan panelis terhadap rasa setiap sampel biskuit mocaf. Tingkat kesukaan panelis hanya mencapai tingkat 5 (agak suka) dapat disebabkan oleh adanya aftertaste pahit yang sedikit terasa oleh panelis. Hal ini disebabkan oleh jenis ubi kayu yang digunakan dalam pembuatan mocaf yaitu jenis ubi kayu pahit. Rasa pahit disebabkan oleh kadar asam sianidanya, semakin tinggi kadar asam sianida dalam umbi, semakin pahit rasanya (Salim 2011).

Berdasarkan hasil analisis kimia pada biskuit mocaf, diperoleh nilai hasil analisis yang dapat dilihat pada Tabel 3 .

\section{Hasil Analisis Kimia}

Tabel 3. Data hasil analisis kimia

\begin{tabular}{ccccc}
\hline Parameter & Satuan & A1 & A2 & A3 \\
& & & & \\
\hline Kadar Air & $\%$ & $3,53 \mathrm{a}$ & $3,83 \mathrm{a}$ & $3,69 \mathrm{a}$ \\
Kadar Abu & $\%$ & $2,07 \mathrm{a}$ & $2,77 \mathrm{a}$ & $3,12 \mathrm{a}$ \\
Kadar Protein & $\%$ & $9,64 \mathrm{a}$ & $10,51 \mathrm{a}$ & $12,19 \mathrm{a}$ \\
Kadar Lemak & $\%$ & $26,46 \mathrm{c}$ & $27,38 \mathrm{~b}$ & $29,23 \mathrm{a}$ \\
Karbohidrat & $\%$ & $58,30 \mathrm{a}$ & $55,51 \mathrm{~b}$ & $51,77 \mathrm{c}$ \\
Serat Kasar & $\%$ & $2,76 \mathrm{a}$ & $1,34 \mathrm{~b}$ & $1,37 \mathrm{~b}$ \\
Energi Total & Kcal/100g & $510 \mathrm{~b}$ & $511 \mathrm{~b}$ & $519 \mathrm{a}$ \\
\hline
\end{tabular}

Keterangan : Huruf yang berbeda dalam satu baris menyatakan berbeda nyata pada $\alpha=0.05$

A1 = Tepung Ikan Lele 11\%: Tepung Kedelai 6\%

A2 = Tepung Ikan Lele 14\%: Tepung Kedelai 3\%

A3 = Tepung Ikan Lele 17\%: Tepung Kedelai 0\% 


\section{Kadar air}

Berdasarkan hasil analisis sidik ragam menunjukan bahwa perbandingan konsentrasi tepung ikan lele dan tepung kedelai tidak berpengaruh nyata terhadap kadar air biskuit mocaf ( $p>0,05)$. Syarat mutu kadar air biskuit berdasarkan SNI 2973-2011 (BSN, 2011a) adalah maximum $5 \%$. Berdasarkan syarat mutu tersebut, kadar air dari ketiga jenis perlakuan biskuit mocaf memiliki niali yang lebih renda. Sehingga kadar air dari ketiga biskuit tersebut sesuai dengan standar.

\section{Kadar abu}

Berdasarkan hasil analisis sidik ragam menunjukan bahwa perbandingan konsentrasi tepung ikan lele dan tepung kedelai tidak berpengaruh nyata terhadap kadar abu biskuit mocaf ( $p>0,05)$. Syarat mutu kadar abu biskuit berdasarkan SNI 012973-1992 (BSN 1992) adalah maksimum $1,6 \%$. Kadar abu dari ketiga jenis perlakuan biskuit mocaf yang dihasilkan lebih besar dari standar. Hal ini menunujukan bahwa biskuit mocaf memiliki kandungan mineral yang cukup tinggi. Hal ini dapat disebabkan oleh pengaruh penambahan tepung ikan lele dumbo yang meningkatkan kandungan mineral produk biskuit mocaf sehingga meningkat pula kadar abunya. Hal ini dikarenakan tepung ikan lele khususnya kepala ikan yang terdiri dari tulang dan hanya sebagian kecil daging. Sehingga sesuai dengan pernyataan Moeljanto (1982) dalam Mervina et al. (2012), yang menyatakan bahwa sebagian besar abu dan mineral dalam tepung ikan berasal dari tulang-tulang ikan.

\section{Kadar protein}

Berdasarkan hasil analisis sidik ragam menunjukan bahwa perbandingan konsentrasi tepung ikan lele dan tepung kedelai tidak berpengaruh nyata terhadap kadar protein biskuit mocaf ( $p>0,05)$. Hal ini dapat disebabkan oleh rentang persentase yang berdekatan antara penambahan tepung ikan lele dan tepung kedelai setiap sampel.
Syarat mutu kadar protein biskuit berdasarkan SNI 2973-2011 (BSN 2011) adalah minimum 5\% (bb). Jika dibandingkan dengan syarat mutu SNI tersebut, kadar protein dari ketiga jenis perlakuan biskuit mocaf telah memenuhi standar. Hasil analisis tersebut juga menunjukan bahwa semakin tinggi konsentrasi tepung ikan lele, kadar protein biskuit akan semakin meningkat meskipun konsentrasi tepung kedelainya semakin rendah. Peningkatan nilai kadar protein ini sesuai dengan penelitian Nugroho et al. (2016), bahwa kadar protein roti tawar meningkat dengan perlakuan penambahan tepung daging ikan lele dumbo. Peningkatan kadar protein juga dapat disebabkan oleh kandungan protein pada tepung ikan lele lebih tinggi dibandingkan dengan tepung kedelai. Diketahui kandungan protein yang tertera pada kemasan tepung ikan lele bagian badan yaitu $56 \%$ dan bagian kepala $42 \%$ sedangkan yang tertera pada kemasan tepung kedelai 45,38\%.

\section{Kadar lemak}

Berdasarkan hasil analisis sidik ragam menunjukan bahwa perbandingan konsentrasi tepung ikan lele dan tepung kedelai berpengaruh nyata terhadap kadar lemak biskuit mocaf $(\mathrm{p}<0,05)$. Hasil uji lanjut duncan diketahui bahwa kadar lemak biskuit mocaf A1 berbeda nyata dengan biskuit mocaf A2 dan A3 ( $p<0,05)$, serta biskuit mocaf A2 berbeda nyata dengan biskuit mocaf A3 $(p<0,05)$

Syarat mutu kadar lemak biskuit berdasarkan SNI 01-2973-1992 (BSN, 1992) adalah minimum 9,5\%. Berdasarkan syarat mutu tersebut, kadar lemak dari ketiga jenis perlakuan biskuit mocaf memiliki nilai yang lebih tinggi. Sehingga dapat dikatakan sesuai dengan standar. Hasil analisis tersebut juga menunjukan bahwa semakin tinggi konsentrasi tepung ikan lele, kadar lemak biskuit akan semakin meningkat meskipun konsentrasi tepung kedelainya semakin rendah. Tepung ikan lele memiliki kadar lemak yang lebih tinggi dibandigkan dengan tepung kedelai. Tepung badan ikan lele merupakan bagian yang paling banyak 
mengandung lemak dibandingkan dengan bagian kepala, karena terdapat bagian daging ikan yang paling banyak. Hal ini sesuai dengan penelitian Kustiani et al. (2017), bahwa penambahan tepung ikan lele dumbo pada formullasi crakers ikan lele : kelor (10: 2,5) berperan dalam peningkatan kandungan lemaknya. Hal ini dikarenakan tepung badan ikan lele dumbo mengandung lemak tinggi sebesar $20,83 \%$ dan tepung kepala ikan lele dumbo sebesar 18,60\%.

Kadar karbohidrat

Kadar karbohidrat pada biskuit dihitung dengan penentuan kadar karbohidrat secara kasar menggunakan metode by difference. Hasil analisis sidik ragam menunjukan bahwa perbandingan konsentrasi tepung ikan lele dan tepung kedelai berpengaruh nyata terhadap kadar karbohidrat biskuit mocaf $(\mathrm{p}<0,05)$. Hasil uji lanjut duncan diketahui bahwa biskuit mocaf A1 berbeda nyata dengan biscuit mocaf A3 ( $p<0,05)$. Biskuit formula A1 memiliki nilai karbohidrat yang tertinggi yaitu dengan penambahan tepung kedelai yang lebih banyak. Hal ini dapat disebabkan oleh penambahan tepung ikan lele dan tepung kedelai yang keduanya memiliki nilai karbohidrat yang cukup tinggi.

\section{Kadar serat}

Hasil analisis sidik ragam menunjukan bahwa perbandingan konsentrasi tepung ikan lele dan tepung kedelai berpengaruh nyata terhadap kadar serat kasar biskuit mocaf $(\mathrm{p}<0,05)$. Hasil uji lanjut duncan diketahui bahwa dari kadar serat kasar biskuit mocaf A1 berbeda nyata dengan biskuit mocaf A2 dan A3 ( $p<0,05)$. Sedangakan kadar serat kasar biskuit mocaf A2 tidak berbeda nyata dengan biskuit mocaf A3 ( $p<0,05)$. Kandungan serat dapat dipengaruhi oleh kadar serat pada tepung kedelai. Menurut data dari USDA (2018), tepung kedelai memiliki kadar serat pangan sebesar $9,7 \%$.

\section{Energi total}

Hasil analisis sidik ragam menunjukan bahwa perbandingan konsentrasi tepung ikan lele dan tepung kedelai berpengaruh nyata terhadap nilai energi biskuit mocaf ( $\mathrm{p}$ $<0,05)$. Hasi uji lanjut duncan diketahui bahwa dari nilai energi biskuit mocaf A3 berbeda nyata dengan biskuit mocaf A1 dan A2 $(p<0,05)$, namun biskuit mocaf A1 tidak berbeda nyata dengan formula $A 2(p<0,05)$. Hal tersebut menunjukan bahwa biskuit formula A3 memiliki nilai energi paling tinggi yang dapat disebabkan oleh hasil analisis protein dan lemak yang juga paling tinggi.

\section{Hasil Analisis Tekstur}

Berdasarkan hasil analisis tekstur pada biskuit mocaf, diperoleh nilai hasil uji kekerasan yang dapat dilihat pada Tabel 4.

Tabel 4. Hasil Uji Kekerasan (Hardness)

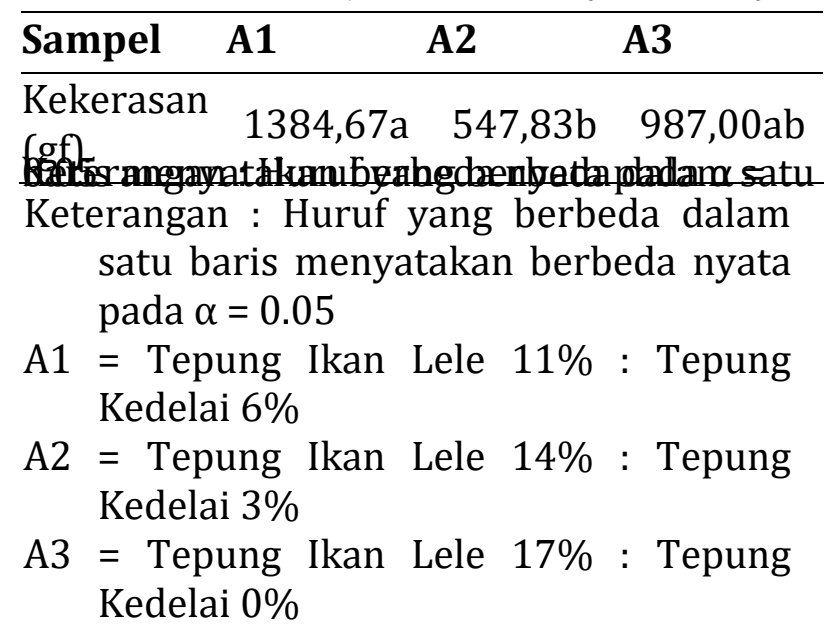

Hasil analisis sidik ragam menunjukan bahwa perbandingan konsentrasi tepung ikan lele dan tepung kedelai berpengaruh nyata terhadap nilai kekerasan biskuit mocaf $(p<0,05)$. Hasil uji lanjut duncan diketahui bahwa dari nilai kekerasan biskuit mocaf $\mathrm{A} 1$ berbeda nyata dengan biskuit mocaf A2 $(p<0,05)$. Sedangkan biskuit mocaf A3 tidak berbeda nyata dengan biskuit mocaf A1 dan A2 ( $p>0,05)$.

Berdasarkan hasil uji kekerasan yang dapat dilihat pada Tabel 4 diketahui bahwa sampel A1 meiliki tingkat kekerasan paling tinggi dan sampel A2 memiliki tingkat kekerasan paling rendah. Tingkat kekerasan pada produk biskuit dikaitkan dengan sifat kerenyahan. Semakin tinggi nilai kekerasan, semakin keras teksturnya dan bersifat kurang renyah dibandingkan produk yang memiliki nilai kekerasan lebih rendah 
(Pitriawati 2008). Nilai kekerasan yang terukur dipengaruhi oleh komposisi penyususun biskuit, suhu, dan lamanya pemanasan (Pratama et al. 2014). Tingkat kekerasan biskuit mocaf untuk lanisa ini mengacu pada tingkat kekerasan biskuit bayi yaitu antara 948-1196 gf yang diketahui mempunyai tekstur tidak terlalu keras dan tidak mudah hancur (Aini dan Wirawani 2013). Sehingga dapat diketahui bahwa sampel biskuit formula A3 memiliki tingkat kekerasan yang sesuai dengan biskut bayi tersebut.

\section{Penentuan Produk Terpilih}

Penentuan produk terpilih dilihat berdasarkan hasil uji hedonik yang dilakukan oleh lansia dapat dilihat pada Tabel 5, nilai energi yang diperoleh dari hasil analisis proksimat dapat dilihat pada Tabel 6, dan hasil analisis kekerasan terhadap biskuit mocaf dapat dilihat pada Tabel 7 .

Tabel 5. Hasil rata-rata uji hedonik produk terpilih A3 (Tepung Ikan lele 17\% : Tepung kedelai $0 \%$ )

\begin{tabular}{cccc} 
Parameter & $\begin{array}{c}\text { Nilai } \\
\text { rata- } \\
\text { rata }\end{array}$ & Keterangan & Persen \\
\hline Warna & 5,26 & Agak suka & $73 \%$ \\
Aroma & 5,46 & Agak suka & $92 \%$ \\
Tekstur & 6,06 & Suka & $90 \%$ \\
Rasa & 5,50 & Agak suka & $84 \%$ \\
\hline
\end{tabular}

Berdasarkan nilai energi, sampel biskuit A3 (tepung ikan lele17\% : tepung kedelai 0\%) memiliki kadar protein tertinggi yaitu $12,19 \%$ dan nilai energi tertinggi yaitu 519 Kkal per 100g, serta dengan tingkat kekerasan yang paling sesuai yaitu padat dan renyah. Sehingga dapat disimpulkan bahwa biskuit formula A3 dengan perbandingan tepung ikan lele dan tepung kedelai 17\%:0\% merupakan produk terpilih dari hasil penelitian ini.
Tabel 6. Hasil rata-rata uji kimia produk terpilih A3 (Tepung Ikan lele 17\% : Tepung kedelai 0\%)

\begin{tabular}{ccc}
\hline Parameter & Satuan & A3 \\
\hline Kadar Air & $\%$ & 3,69 \\
Kadar Abu & $\%$ & 3,12 \\
Kadar Protein & $\%$ & 12,19 \\
Kadar Lemak & $\%$ & 29,23 \\
Karbohidrat & $\%$ & 51,77 \\
Serat Kasar & $\%$ & 1,37 \\
Energi Total & Kkal/100g & 519 \\
\hline
\end{tabular}

Tabel 7. Hasil rata-rata uji kekerasan produk terpilih A3 (Tepung Ikan lele $17 \%$ : Tepung kedelai $0 \%$ )

\begin{tabular}{cc}
\hline Sampel & A3 \\
\hline Kekerasan (gf) & 987,00 \\
\hline
\end{tabular}

Berdasarkan angka kebutuhan gizi lansia menurut kementrian kesehatan (2013), kebutuhan kalori wanita lansia sebanyak $1900 \mathrm{Kkal}$ per hari dan pria lansia sebanyak 2325 Kkal per hari. Satu keping biskuit produk terpilih dengan bobot ratarata 8,4 gram mengandung 44 Kkal. Jika dalam satu kali makan lansia mengkonsumsi 2 keping biskuit, maka dapat memberi asupan energi sebanyak 4,6\% untuk wanita lansia dan 3,8\% untuk pria lansia.

\section{KESIMPULAN DAN SARAN}

\section{Kesimpulan}

Berdasarkan hasil penelitian yang dilakukan untuk mengetahui pengaruh penambahan tepung ikan lele dan tepung kedelai terhadap nilai fisik dan kimia biskuit, serta tingkat kesukaan panelis lansia yang terpilih yaitu biskuit mocaf dengan penambahan tepung ikan lele $17 \%$ dan tepung kedelai 0\%. Biskuit tersebut memiliki kandungan gizi sebagai berikut : kadar air $3,69 \%$, kadar abu 3,12\%, kadar protein 12,19\%, kadar lemak 29,23\%, kadar karbohidrat $51,77 \%$, kadar serat kasar1,37\%, dan energi total 519 Kkal per 100 gram dengan nilai kekerasan sebesar 987,00 gf (gramforce). 


\section{Saran}

Perlu dilakukan pengurangan konsentrasi tepung mocaf dan juga pemilihan terhadap produk, karena dapat menimbulkan aftertaste yang pahit. Perlu dilakukan perbaikan terhadap warna dan bentuk biskuit agar lebih menarik bagi lansia, serta penambahan konsentrasi perisa berbasis rempah untuk menutupi bau amis dari tepung ikan lele.

\section{DAFTAR PUSTAKA}

Aini NQ dan Wirawani Y. 2013. Kontribusi mp-asi biskuit substitusi tepung garut, kedelai, dan ubi jalar kuning terhadap kecukupan protein, vitamin A, kalsium, dan zink pada bayi. Journal of Nutrition College 2(4): 458-466.

Almatsier S. 2001. Prinsip Dasar Ilmu Gizi. PT Gramedia Pustaka Utama, Jakarta.

[AOAC] Association of Official Analitycal Chemist. 2000. Official Method of Analysis of The Association of Official Analytical of Chemist. Arlington, Virginia, USA: Association of Official Analytical Chemist, Inc.

[BSN] Badan Standardisasi Nasional. 1992. SNI 2973 : 1992 tentang Mutu dan cara uji biskuit. Badan Standardisasi Nasional, Jakarta.

[BSN] Badan Standardisasi Nasional. 2011a. SNI 2973 : 2011 tentang Biskuit. Badan Standardisasi Nasional, Jakarta

[BSN] Badan Standardisasi Nasional. 2011b. SNI 7622 : 2011 tentang Tepung Mocaf. Badan Standardisasi Nasional, Jakarta.

Kustiani A, Kusharto CM, Damayanthi E. 2017. Pengembangan crackers sumber protein dan mineral dengan penambahan tepung daun kelor (Moringa oleifera) dan tepung badan-kepala ikan lele dumbo (Clarias gariepinus). Jurnal Nutri Sains 1(1) : 1-17

Meirina. 2011. Hubungan dukungan keluarga, karakteristik keluarga dan lansia dengan pemenuhan nutrisi pada lansia di wilayah kerja Puskesmas Bogor Selatan [Thesis]. Universitas Indonesia, Depok.

Mervina, Kusharto CM, dan Marliyati SA. 2012. Formulasi biskuit dengan subtitusi tepung ikan lele dumbo (Clarias gariepinus) dan isolat protein kedelai (Glycine max) sebagai makanan potensial untuk anak balita gizi kurang. Jurnal Teknologi dan Industri Pangan 23(1): 9-1

Midlanda HM, Lubis LM, Lubis Z. 2012. Pengaruh metode pembuatan tepung jagung dan perbandingan tepung jagung dan tepung beras terhadap mutu cookies. Jurnal Rekayasa Pangan Pert. 2(4): 20-31

Nastiti AN, dan Christyaningsih J. 2019. Pengaruh substitusi tepung ikan lele terhadap pembuatan cookies bebas gluten dan kasein sebagai alternatif jajanan anak autism spectrum disorder. Jurnal Media Gizi Indonesia 14(1):35-4

Nugroho HI, Dewi EN, Rianingsih L. 2016. Pengaruh penambahan tepung daging ikan lele dumbo (Clarias gariepinus) terhadap nilai gizi roti tawar. Jurnal Pengolahan dan Biotek Hasil Penelitian 5 (4): 11-1

Pitriawati R. 2008. Sifat fisik dan organoleptik snack ekstrusi berbahan baku grits jagung yang disubstitusi dengan tepung putih telur [Skripsi]. Fakultas Peternakan. Institut Pertanian Bogor, Bogor.

Pratama RI, Rostini I, Liviawaty, E. 2014. Karakteristik biskuit dengan penambahan tepung tulang ikan jangilus (Istiophorus sp). Jurnal Akuantika 5(1): 30-39

Salim E. 2011. Mengolah Singkong Menjadi Tepung Mocaf. Andi Offset, Yogyakarta.

Septieni D. 2016. Mempelajari pembuatan cookies kaya serat dengan bahan dasar tepung asia ubi jalan [Skripsi]. Fakultas Teknologi Pertanian. Institut Pertanian Bogor, Bogor. 
[USDA] United States Department of Winarno F.G. 2004. Kimia Pangan dan Gizi. Agriculture. 2018. Basic Report 16116, Gramedia Pustaka Utama, Jakarta. Soy flour, full-fat, roasted. 